\title{
VEGFD wt Allele
}

National Cancer Institute

\section{Source}

National Cancer Institute. VEGFD wt Allele. NCI Thesaurus. Code C104386.

Human VEGFD wild-type allele is located in the vicinity of Xp22.2 and is approximately 39 $\mathrm{kb}$ in length. This allele, which encodes vascular endothelial growth factor $\mathrm{D}$, is involved in endothelial cell growth, angiogenesis, and lymphang iogenesis. 